\title{
Helicobacter pylori detection in gastric biopsies, saliva and dental plaque of Brazilian dyspeptic patients
}

\author{
Lucas Trevizani Rasmussen¹, Roger William de Labio², Luciano Lobo Gatti³,Luiz Carlos da Silva4, \\ Valdeir Fagundes de Queiroz ${ }^{5}$, Marília de Arruda Cardoso Smith ${ }^{6}$, Spencer Luiz Marques Payão, 2/+ \\ ${ }^{1}$ Universidade do Sagrado Coração, Bauru, SP, Brasil ${ }^{2}$ Disciplina Genética, Hemocentro ${ }^{4}$ Disciplina de Anatomia Patológica \\ ${ }^{5}$ Disciplina de Cirurgia do Sistema Digestório, Faculdade de Medicina de Marília, Rua Lourival Freire 240, 17519-050, Marília, SP, Brasil \\ ${ }^{3}$ Faculdades Integradas de Ourinhos, Ourinhos, SP, Brasil ${ }^{6}$ Departamento de Morfologia, Escola Paulista de Medicina, \\ Universidade Federal de São Paulo, São Paulo, SP, Brasil
}

Helicobacter pylori is an important human pathogen that causes chronic gastritis and is associated with the development of peptic ulcer disease and gastric malignancies. The oral cavity has been implicated as a potential H. pylori reservoir and may therefore be involved in the reinfection of the stomach, which can sometimes occur following treatment of an $\mathrm{H}$. pylori infection. The objectives of this paper were (i) to determine the presence of $\mathrm{H}$. pylori in the oral cavity and (ii) to examine the relationship between oral $\mathrm{H}$. pylori and subsequent gastritis. Gastric biopsies, saliva samples and dental plaques were obtained from 78 dyspeptic adults. DNA was extracted and evaluated for the presence of $\mathrm{H}$. pylori using polymerase chain reaction and Southern blotting methods. Persons with gastritis were frequently positive for $\mathrm{H}$. pylori in their stomachs $(p<0.0001)$ and there was a statistically significant correlation between the presence of $\mathrm{H}$. pylori in gastric biopsies and the oral cavity $(p<0.0001)$. Our results suggest a relationship between gastric infection and the presence of this bacterium in the oral cavity. Despite this, H. pylori were present in the oral cavity with variable distribution between saliva and dental plaques, suggesting the existence of a reservoir for the species and a potential association with gastric reinfection.

Key words: Helicobacter pylori - oral infection - saliva - dental plaque

Helicobacter pylori is a spiral-shaped, Gram-negative bacterium that persistently colonises the gastric mucosa of humans. This bacterium plays an important role in the initiation of gastrointestinal diseases, particularly peptic and duodenal ulcers, as well as gastric cancer and lymphoid tissue lymphoma. $H$. pylori is estimated to inhabit at least half the world's human population (Erzin et al. 2006, Huang et al. 2009, Nouraie et al. 2009).

Numerous retrospective and prospective studies have shown a significant correlation between $H$. pylori infection and distal gastric cancer risk (Kignel et al. 2005, De Vries et al. 2007). Additionally, H. pylori infection is associated with low socioeconomic status, crowded living condition and poor personal hygiene. The infection is usually acquired in early childhood (Nahar et al. 2009).

The prevalence of $H$. pylori infection in gastric biopsies appears to be higher in developing countries compared to developed countries. In Brazil, the prevalence of $H$. pylori infection may be as high as $80 \%$ in adults, whereas the prevalence is typically $30-70 \%$ in North America and Europe (Souto et al. 1998, Mitchell 1999, Brito et al. 2003, Mitchell et al. 2003, Tseng et al. 2006, Yamaoka 2008). Despite these dramatic infection rates,

Financial support: FAPESP (06/60836-1), CAPES, USC, FAMEMA

+ Corresponding author: slmpayao@famema.br

Received 4 November 2009

Accepted 24 March 2010 the modes of acquisition and transmission of $\mathrm{H}$. pylori remain unclear. Fecal-oral, oral-oral and gastro-oral routes have all been implicated in the transmission of the bacteria.

It is well-established that the principal ecological niche for H. pylori is the gastric mucosa. Recent studies using the polymerase chain reaction (PCR) technique for $H$. pylori diagnosis have demonstrated that $H$. pylori can be found in the human oral cavity, but it is unclear whether that cavity is a permanent or transient reservoir. This region of the body provides an excellent microaerophilic environment and is therefore a potential reservoir for $H$. pylori (Dowsett \& Kowolik 2003, Loster et al. 2006, Burgers et al. 2008). Some investigators believe that $H$. pylori belongs to the normal microbiota of the human oral cavity and maintains a commensal relationship with the human host. In contrast, other authors have suggested that $H$. pylori intermittently colonises oral cavities as a result of the ingestion of contaminated foods or as a secondary effect of gastro-esophageal reflux (De Sousa et al. 2006, Salmanian et al. 2008, Souto \& Colombo 2008).

One of the first investigations of the influence of oral H. pylori on stomach infection was carried out by Miyabayashi et al. (2000). This study confirmed the relationship between gastritis induced by $H$. pylori infection and oral colonisation of the bacterium. Moreover, these authors also attempted to elucidate the resistance of oral $H$. pylori to typical triple anti-H. pylori therapy that is used to eradicate the germ from the stomach. They determined that patients with oral H. pylori were at a 
significantly greater risk of gastric reinfection following successful therapy. Thus, this study emphasised a clear link between the presence of $H$. pylori in the oral cavity and the infection of gastric mucosa (Loster et al. 2006).

Previous research has laid the groundwork for the present paper. H. pylori has been suggested to colonise the mouth of persons with gastritis; however, the support for this hypothesis is unclear. Therefore, the objectives of this paper were (i) to determine the presence of $H$. pylori in the oral cavity and (ii) to examine the relationship between the presence of the bacteria in the oral cavity and gastric mucosa.

\section{PATIENTS, MATERIALS AND METHODS}

Seventy-eight adults (36 male and 42 female with a mean age 51.2 years) presenting recurrent abdominal pain participated in the study. All subjects were recruited from Ambulatório de Endoscopia of Faculdade de Medicina de Marília, São Paulo, Brazil. All subjects signed an informed consent form that was approved by the local Ethical Committee.

Three biopsies were obtained from the gastric antrum of each patient. The first antrum specimen was used for the rapid urease test, the second specimen was used for histology and the third for molecular analysis. Dental plaque and saliva was also acquired from each subject. Subjects who were HIV-positive or had taken anti- inflammatory or antimicrobials drugs within the previous two months were excluded from the study.

Rapid urease test and histology - Infection was determined by a Rapid urease test, using the TUPF kit (Laborclin, Brazil), according to the manufacturer's instructions. Samples were examined within $24 \mathrm{~h}$ of collection. Urea hydrolysis and histopathological examinations were conducted to determine the presence of $H$. pylori in accordance with the updated Sydney System.

Collection and DNA extraction from saliva and dental plaque - Saliva and plaque samples were collected from each subject prior to endoscopic examination. Salivary flow was stimulated for each patient and $3 \mathrm{~mL}$ of saliva was collected in test tubes. Dental plaque from all regions of the oral cavity (incisors, canines, premolars and molars) was removed with a sterile curette and transferred to $15 \mathrm{~mL}$ of phosphate buffered saline.
DNA extraction from dental plaques and saliva was performed as previously described (Okada et al. 2000, Kignel et al. 2005). Briefly, $10 \mathrm{~mL}$ of dental plaque suspension or $1 \mathrm{~mL}$ saliva were centrifuged for $5 \mathrm{~min}$ at $10,000 \mathrm{rpm}$. The pellets were suspended in $480 \mu \mathrm{L}$ of digestion buffer (5 mM EDTA, pH 8, 0.5 mol Tris- $\mathrm{HCl}, \mathrm{pH}$ 7.5 and $5 \%$ Tween 20 ) and $20 \mu \mathrm{L}$ of $100 \mu \mathrm{g} / \mathrm{mL}$ proteinase $\mathrm{K}$ and incubated at $55^{\circ} \mathrm{C}$ overnight. DNA was extracted twice with an equal volume of phenol-chloroform and then precipitated with a double volume of $100 \%$ ethanol. Finally, the extracted DNA was resuspended in $80 \mu \mathrm{L}$ to $100 \mu \mathrm{L}$ of TE buffer.

Preparation of the DNA probe - A 150-base-pair fragment was amplified by PCR from genomic DNA of cultured H. pylori using the Hpx1 and Hpx2 primers. This fragment was then used as the probe for the hybridisations. After amplification, the reaction mixture was electrophoresed in $2 \%$ agarose gels and the 150 base pair fragment of interest was recovered from an agarose gel and purified using GFX PCR DNA and Gel Band Purification Kit (Amersham Pharmacia, USA). The probe was synthesised using the Kit Gene Images AlkPhos Direct Labelling (Amersham Pharmacia, USA), according to the manufacturer's instructions.

Statistical analysis - Statistical analysis was performed by $\aleph^{2}$ and Kappa test. The significance level was set at a $\mathrm{p}$ value of $<0.05$.

\section{RESULTS}

Detection of $H$. pylori from gastric biopsies by PCR, Southern blotting, histology and urease test - We utilised several methods to test for the presence of $H$. pylori in gastric biopsies of all 78 adult patients, the results of which are presented in Table I. In our PCR analysis, 46 (59\%) of the patients presented with $H$. pylori infection. Combining that data with the results of our Southern blots caused the number of $H$. pylori infected patients to increase from $46-66(84.6 \%)$, with $25.6 \%$ of positive samples showing a significant increase $(\mathrm{p}<0.0001)$ (Figure). In addition, we examined the histology of these biopsies and found that $54(69.2 \%)$ patients had chronic gastritis and $24(30.8 \%)$ patients demonstrated normal mucosa without gastric alterations. Furthermore, our histological analysis showed the presence of $H$. pylori in

\section{TABLE I}

Comparison of the diagnostic methods for Helicobacter pylori (urease test, histology, PCR and Southern blotting) in 78 dyspeptic adults

\begin{tabular}{lcccc}
\hline & $\begin{array}{c}\text { Urease test } \\
\mathrm{n}(\%)\end{array}$ & $\begin{array}{c}\text { Histology } \\
\mathrm{n}(\%)\end{array}$ & $\begin{array}{c}\text { PCR } \\
\mathrm{n}(\%)\end{array}$ & $\begin{array}{c}\text { Southern blotting } \\
\mathrm{n}(\%)\end{array}$ \\
\hline $\begin{array}{l}\text { H. pylori-positive } \\
\text { H. pylori-negative }\end{array}$ & $30(38.5)$ & $21(27)$ & $46(59)$ & $66^{a}(84.6)$ \\
\hline Total & $48(61.5)$ & $57(73)$ & $32(41)$ & $12(15.4)$ \\
\hline
\end{tabular}

$a: \mathrm{p}<0.0001$. 
TABLE II

Detection of Helicobacter pylori DNA in gastric biopsies saliva and dental plaque by Southern blotting

\begin{tabular}{lccc}
\hline & $\begin{array}{c}\text { Gastric mucosa } \\
\mathrm{n}(\%)\end{array}$ & $\begin{array}{c}\text { Saliva } \\
\mathrm{n}(\%)\end{array}$ & $\begin{array}{c}\text { Dental plaque } \\
\mathrm{n}(\%)\end{array}$ \\
\hline H. pylori-positive & $66^{a}(84.6)$ & $33(42.3)$ & $37(47.4)$ \\
H. pylori-negative & $12(15.4)$ & $45(57.7)$ & $41(52.6)$ \\
\hline Total & & $78(100)$ & \\
\hline
\end{tabular}

$a: \mathrm{p}<0.0001$.

$21(27 \%)$ subjects and the urease test detected $H$. pylori infection in $30(38.5 \%)$ patients. It should be noted that both of these techniques showed decreased sensitivity and specificity when compared with the results of PCR and Southern blot hybridisation.

Detection of $H$. pylori in saliva and dental plaque by Southern blotting - We performed Southern blots of DNA extracts from the saliva and dental plaque of all 78 patients. H. pylori was found in the saliva of $33(42.3 \%)$ patients and in the dental plaque of $37(47.4 \%)$ patients (Table II) (Figure). Of the 66 patients who were H. pylori positive in their gastric biopsies, 19 (28.8\%) were found not to have $H$. pylori in the oral cavity. Of the 12 patients whose gastric biopsies were negative for $H$. pylori, six $(50 \%)$ were found not to have H. pylori in the oral cavity. In total, $H$. pylori DNA was detected in all three samples - gastric mucosa, saliva and dental plaque - in 14 (21\%) patients. H. pylori was detected in gastric biopsies and either the saliva or the dental plaque in $33(50 \%)$ subjects.

No statistically significant difference was observed between strains in the saliva and dental plaque. However, a statistically significant correlation was observed between the presence of $H$. pylori in the gastric biopsies and the oral cavity $(\mathrm{p}<0.0001)$.

\section{DISCUSSION}

H. pylori is the causative agent of chronic superficial gastritis and plays an important role in the aetiology of peptic ulcer disease. Evidence suggests that $H$. pylori infection pre-exists the development of gastric carcinoma and is a risk factor for the development of other gastric diseases (Gatti et al. 2005). Because of the importance of this bacterium in the development of chronic gastritis, we evaluated the association between the presence of H. pylori in gastric biopsies and in the saliva and dental plaques of the same dyspeptic adult individuals.

Previous studies (Tiwari et al. 2005, Loster et al. 2006, Souto \& Colombo 2008, Harris et al. 2008) used PCR to diagnose an infection of $H$. pylori. These results are comparable to the results of the present study, in which there was a $95 \%$ success rate in the detection of H. pylori in the stomach. Li et al. (1995) and Song et al. (2000) showed a significant increase in the sensitivity of detection after using Southern blotting and also verified a high prevalence of infection.
The high sensitivity and specificity of the PCR test with hybridisation and the probe used and synthesised from genomic DNA of cultured $H$. pylori decrease the possibility of finding false positives or false negatives or of contamination (Clayton et al. 1991, Song et al. 1999). In addition, we used a pair of primers, designated Hpx1/ Hpx2, that were specific for a $150 \mathrm{bp}$ fragment of $16 \mathrm{~S}$ rRNA of $H$. pylori, which is the most conserved region of the genome, introducing a higher sensitivity and specificity when compared to other primers specific to H. pylori.

Our results parallel previous studies and have revealed that the prevalence of the organism in adults can exceed $80 \%$. However, it is important to remember that the infection rates can vary dramatically by geographic area, age, race and socioeconomic status (Mitchell et al. 2003, Souto \& Colombo 2008).

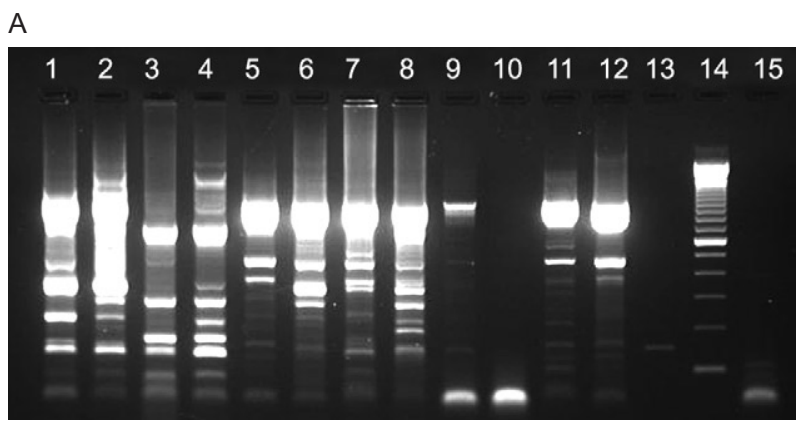

B

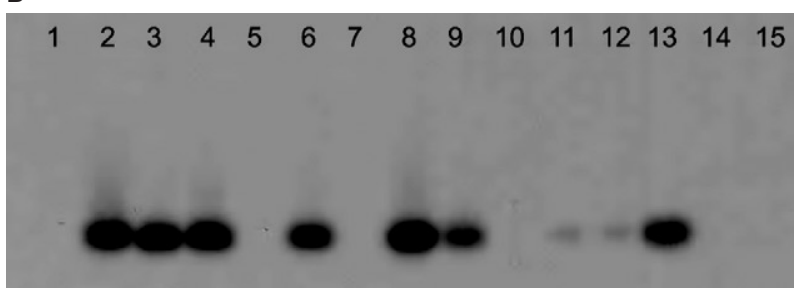

A: agarose gel $2 \%$ showing Helicobacter pylori PCR products of strains of gastric biopsies, saliva and dental plaques (Slots 1, 3, 5, 7: saliva samples; $2,4,6,8$ : dental plaques samples; 9-12: gastric biopsies samples; 13, 15: controls positive and negative, respectively; 14 : Ladder Marker 100 bp (Invitrogen); B: autorradiograph after hybridization with specific chemiluminescent probe referent to A (Slots 1, 5, 7: H. pylori-negative saliva samples; 3 : H. pylori-positive saliva sample; $2,4,6,8:$ H. pylori-positive dental plaques samples; $10: H$. pylorinegative gastric biopsy sample; 9, 11, 12: $H$. pylori-positive gastric biopsies samples; 13, 15: control positive and negative, respectively). 
Several authors (Madmujar et al. 1990, Krajden et al. 1989, Nguyen et al. 1995, Loster et al. 2006, De Sousa et al. 2006, Souto \& Colombo 2008, Silva et al. 2009) have reported that the oral cavity can be a reservoir for $H$. pylori, making treatment difficult and exposing the individual to a higher risk of gastric reinfection. However, Okada et al. (2000), Dye et al. (2002) and Olivier et al. (2006) have characterised the bacterium in the oral cavity as being mainly transient. Despite this, these authors do not discard the hypothesis that an association between the presence of the bacteria in the stomach and mouth may exist.

In our study, $33(42.3 \%)$ and $37(47.4 \%)$ of the patients had H. pylori in saliva and dental plaque samples, respectively. Li et al. (1995) found $75 \%$ of saliva samples to be positive, which is similar to the results of Wang et al. (2002), who found the bacterium in $71 \%$ of saliva samples. Tiwari et al. (2005) studied 120 dyspeptic patients and detected $H$. pylori in the gastric and saliva samples from each patient. Both authors suggested that saliva may be a method of transmission and may potentially induce gastric reinfections, which supports the results of the present study.

Song et al. (2000) analysed 117 samples of dental plaque from 42 patients and verified the presence of the bacterium in $68 \%$ of the samples. These results are similar to those of Liu et al. (2009), who found positive samples in $59 \%$ of their subjects. It is interesting to note that these studies differ from the results of Kignel et al. (2005), who found a low prevalence in gastric biopsy samples and only one positive dental plaque sample. Similarly, Souto and Colombo (2008) found that 20\% and $33 \%$ of subjects had positive samples in saliva and dental plaque, respectively.

Silva et al. (2009) used a control group (individuals with no gastric disease who were $H$. pylori positive) and a case group (individuals with gastric disease who were H. pylori positive). The results from that study showed the presence of $H$. pylori in saliva and dental plaques from only the patients in the case group, suggesting an association between the oral cavity and gastric disease.

Inconsistent differences in the frequency of $H$. $p y$ lori in the oral cavity are found in the literature. These differences may be a consequence of variations in the demographics of subjects, oral health status, H. pylori infection status, type and number of clinical samples, complexity of the oral microbiota and methods of detection (Souto \& Colombo 2008).

Kignel et al. (2005) reported that the levels of bacteria in the oral cavity may be too low to be detected by one round of PCR. They further emphasised that the location in the mouth used for the collection of the samples can influence the prevalence of the microorganism. This idea was further supported by the results of Song et al. (2000), who found a prevalence of $82 \%$ in the molar region, $64 \%$ in pre-molar region and 59\% in the incisor region. Loster et al. (2006) suggested that this variation may be the result of dental plaques being exposed to different levels of oxygenation, which can affect colonisation by $H$. pylori. The prevalence of infection in saliva and dental plaques, collectively, was $70 \%$ in this study.
In sum, our results verified a possible correlation between the prevalence of $H$. pylori in the oral cavity and infection in the stomach in Brazilian adult patients.

Our results suggest a relationship between gastric infection and the presence of $H$. pylori in the oral cavity. H. pylori were present in the oral cavity with a variable distribution between saliva and dental plaques, suggesting the existence of a reservoir for the species and a potential association with gastric reinfection.

\section{REFERENCES}

Brito CA, Silva LM, Jucá N, Leal NC, de Souza W, Queiroz D, Cordeiro F, Silva NL 2003. Prevalence of cagA and vacA genes in isolates from patients with Helicobacter pylori-associated gastroduodenal diseases in Recife, Pernambuco, Brazil. Mem Inst Oswaldo Cruz 98: 817-821.

Bürgers R, Schneider-Brachert W, Reischl U, Behr A, Hiller KA, Lehn N, Schmalz G, Ruhl S 2008. Helicobacter pylori in human oral cavity and stomach. Eur J Oral Sci 116: 297-304.

Clayton C, Kleanthous K, Tabaqchali S 1991. Detection and identification of Helicobacter pylori by the polymerase chain reaction. J Clin Pathol 44: 515-516.

De Sousa L, Vásquez L, Velasco J, Parlapiano D 2006. Isolation of Helicobacter pylori in gastric mucosa, dental plaque and saliva in a population from the Venezuelan Andes. Invest Clin 47: 109-116.

De Vries AC, Kuipers EJ 2007. Helicobacter pylori eradication for the prevention of gastric cancer. Aliment Pharmacol Ther 26: 25-35.

Dowsett SA, Kowolik MJ 2003. Oral Helicobacter pylori: can we stomach it? Crit Rev Oral Biol Med 14: 226-233.

Dye BA, Kruszon-Moran D, McQuillan G 2002. The relationship between periodontal disease attributes and Helicobacter pylori infection among adults in the United States. Am J Public Health 92: 1809-1815.

Erzin Y, Koksal V, Altun S, Dobrucali A, Aslan M, Erdamar S, Dirican A, Kocazeybek B 2006. Prevalence of Helicobacter pylori $v a c \mathrm{~A}, c a g \mathrm{~A}, \operatorname{cag\mathrm {E}}$, ice $\mathrm{A}, \operatorname{bab\mathrm {A}2}$ genotypes and correlation with clinical outcome in Turkish patients with dyspepsia. Helicobacter 11: 574-580.

Gatti LL, Fagundes e Souza EK, Leite KR, Bastos EL, Vicentini LR, Silva LC, Smith Mde A, Payão 2005. cagA vacA alelles and babA2 genotypes of Helicobacter pylori associated with gastric disease in Brazilian adult patients. Diagn Microbiol Infect Dis 51: 231-235.

Harris PR, Wright SW, Serrano C, Riera F, Duarte I, Torres J, Peña A, Rollán A, Viviani P, Guiraldes E, Schmitz JM, Lorenz RG, Novak L, Smythies LE, Smith PD 2008. Helicobacter pylori gastritis in children is associated with a regulatory T-cell response. Gastroenterology 134: 491-499.

Huang ZG, Duan GC, Fan QT, Zhang WD, Song CH, Huang XY, Zhang RG 2009. Mutation of cytotoxin-associated gene A affects expressions of antioxidant proteins of Helicobacter pylori. World J Gastroenterol 15: 599-606.

Kignel S, de Almeida Pina F, André EA, Alves Mayer MP, Birman EG 2005. Occurrence of Helicobacter pylori in dental plaque and saliva of dyspeptic patients. Oral Dis 11: 17-21.

Krajden S, Fuksa M, Anderson J, Kempston J, Boccia A, Petrea C, Babida C, Karmali M, Penner JL 1989. Examination of human stomach biopsies, saliva and dental plaque for Campylobacter pylori. J Clin Microbiol 27: 1397-1398.

Li C, Musich PR, Ha T, Ferguson DA Jr, Patel NR, Chi DS, Thomas E 1995. High prevalence of Helicobacter pylori in saliva demonstrated by a novel PCR assay. J Clin Pathol 48: 662-666. 
Liu Y, Yue H, Li A, Wang J, Jiang B, Zhang Y, Bai Y 2009. An epidemiologic study on the correlation between oral Helicobacter pylori and gastric H. pylori. Curr Microbiol 58: 449-453.

Loster BW, Majewski SW, Cześnikiewicz-Guzik M, Bielanski W, Pierzchalski P, Konturek SJ 2006. The relationship between the presence of Helicobacter pylori in the oral cavity and gastric in the stomach. J Physiol Pharmacol 57: 91-100.

Majmudar P, Shah SM, Dhunjibhoy KR, Desai HG 1990. Isolation of Helicobacter pylori from dental plaques in healthy volunteers. Indian J Gastroenterol 4: 271-272.

Mitchell A, Silva TM, Barrett LJ, Lima AA, Guerrant RL 2003. Agespecific Helicobacter pylori seropositivity rates of children in an impoverished urban area of Northeast Brazil. J Clin Microbiol 41: $1326-1328$.

Mitchell HM 1999. The epidemiology of Helicobacter pylori. Curr Top Microbiol Immunol 241: 11-30.

Miyabayashi H, Furihata K, Shimizu T, Ueno I, Akamatsu T 2000. Influence of oral Helicobacter pylori on the success of eradication therapy against gastric Helicobacter pylori. Helicobacter 5: 30-37.

Nahar S, Kibria KM, Hossain ME, Sultana J, Sarker SA, Engstrand L, Bardhan PK, Rahman M, Endtz HP 2009. Evidence of intra-familial transmission of Helicobacter pylori by PCR-based RAPD fingerprinting in Bangladesh. Eur J Clin Microbiol Infect Dis 28: 767-773.

Nguyen AM, el-Zaatari FA, Graham DY 1995. Helicobacter pylori in the oral cavity. A critical review of the literature. Oral Surg Oral Med Oral Pathol Oral Radiol Endod 79: 705-709.

Nouraie M, Latifi-Navid S, Rezvan H, Radmard AR, Maghsudlu M, Zaer-Rezaii H, Amini S, Siavoshi F, Malekzadeh R 2009. Childhood hygienic practice and family education status determine the prevalence of Helicobacter pylori infection in Iran. Helicobacter 14: 40-46.

Okada M, Hayashi F, Nagasaka N 2000. Detection of Actinobacillus actinomycetemcomitans and Porphyromonas gingivalis in dental plaque samples from children 2 to 12 years of age. J Clin Periodontol 27: 763-768.

Olivier BJ, Bond RP, van Zyl WB, Delport M, Slavik T, Ziady C, Terhaar Sive Droste JS, Lastovica A, van der Merwe SW 2006. Absence of Helicobacter pylori within the oral cavities of members of a healthy South African community. J Clin Microbiol 44: 635-636.
Salmanian AH, Siavoshi F, Akbari F, Afshari A, Malekzadeh R 2008. Yeast of the oral cavity is the reservoir of Heliobacter pylori. J Oral Pathol Med 37: 324-328.

Scholte GH, van Doorn LJ, Quint WG, Lindeman J 1997. Polymerase chain reaction for the detection of Helicobacter pylori in formaldehyde-sublimate fixed, paraffin-embedded gastric biopsies. Diagn Mol Pathol 6: 238-243.

Silva DG, Stevens RH, Macedo JM, Albano RM, Falabella ME, Veerman EC, Tinoco EM 2009. Detection of cytotoxin genotypes of Helicobacter pylori in stomach, saliva and dental plaque. Arch Oral Biol 54: 684-688.

Song Q, Haller B, Schmid RM, Adler G, Bode G 1999. Helicobacter pylori in dental plaque: a comparison of different PCR primer sets. Dig Dis Sci 44: 479-484.

Song Q, Lange T, Spahr A, Adler G, Bode G 2000. Characteristic distribution pattern of Helicobacter pylori in dental plaque and saliva detected with nested PCR. J Med Microbiol 49: 349-353.

Souto FJ, Fontes CJ, Rocha GA, de Oliveira AM, Mendes EN, Queiroz DM 1998. Prevalence of Helicobacter pylori infection in a rural area of the state of Mato Grosso, Brazil. Mem Inst Oswaldo Cruz 93: 171-174.

Souto R, Colombo AP 2008. Detection of Helicobacter pylori by polymerase chain reaction in the subgingival biofilm and saliva of non-dyspeptic periodontal patients. J Periodontol 79: 97-103.

Tiwari SK, Khan AA, Ahmed KS, Ali SM, Ahmed I, Habeeb A, Kauser F, Hussain MA, Ahmed N, Habibullah CM 2005. Polymerase chain reaction based analysis of the cytotoxin associated gene pathogenicity island of Helicobacter pylori from saliva: an approach for rapid molecular genotyping in relation to disease status. J Gastroenterol Hepatol 20: 1560-1566.

Tseng FC, Brown EE, Maiese EM, Yeager M, Welch R, Gold BD, Owens M, Cranston B, Hanchard B, El-Omar E, Hisada M 2006. Polymorphisms in cytokine genes and risk of Helicobacter pylori infection among Jamaican children. Helicobacter 11: 425-430.

Yamaoka Y 2008. Roles of the plasticity regions of Helicobacter pylori in gastroduodenal pathogenesis. J Med Microbiol 57: 545-553.

Wang J, Chi DS, Laffan JJ, Li C, Ferguson DA Jr, Litchfield P, Thomas E 2002. Comparison of cytotoxin genotypes of Helicobacter pylori in stomach and saliva. Dig Dis Sci 47: 1850-1856. 